\title{
Surface Modification of Titanium with Hydrothermal Treatment at High Pressure
}

\author{
Razia SULTANA ${ }^{1}$, Masayuki KON², Luciana M. HIRAKATA ${ }^{3}$, Emi FUJIHARA², Kenzo ASAOKA ${ }^{2}$ \\ and Tetsuo ICHIKAWA ${ }^{1}$ \\ ${ }^{1}$ Department of Oral and Maxillofacial Prosthodontics and Oral Implantology, Institute of Health Biosciences, Tokushima \\ University Graduate School, 3-18-15 Kuramoto, Tokushima 770-8504, Japan \\ ${ }^{2}$ Department of Biomaterials and Bioengineering, Course of Maxillo-Oral and Regenerative Medicine, Institute of Health \\ Biosciences, Tokushima University Graduate School, 3-18-15 Kuramoto, Tokushima 770-8504, Japan \\ ${ }^{3}$ Department of Prosthodontics, School of Dentistry, Pontifical Catholic University of Rio Grande do Sul, Rio Grande do Sul, \\ Brazil \\ Corresponding author, Masayuki Kon E-mail:massy@dent.tokushima-u.ac.jp
}

Received February 28, 2006/Accepted May 24, 2006

\begin{abstract}
Surface modification of titanium was investigated by means of hydrothermal treatment with a maximum pressure of 6.3 $\mathrm{MPa}\left(280^{\circ} \mathrm{C}\right.$ temperature) in $\mathrm{CaO}$ solution or water to improve bioactivity and biocompatibility. As a result, calcium titanate was formed on the titanium surface. Moreover, titanium oxide and titanium hydroxide layers on the surface increased as temperature and pressure increased. The surface-modified titanium was also immersed in a simulated body fluid $(\mathrm{SBF})$ to estimate its bioactivity. Needle-like apatite precipitation was observed on all hydrothermal-treated titanium surfaces after immersion in SBF for four weeks. In particular, the apatite precipitation of titanium treated with $6.3 \mathrm{MPa}$ in $\mathrm{CaO}$ solution was clearer and larger in amount than those of all other hydrothermal-treated specimens. Further, the amount of precipitate corresponded to the thickness of the surface-modified layer and the amount of calcium in the surface layer. The results suggested that surface modification of titanium with high-pressure hydrothermal treatment seemed to improve bioactivity and biocompatibility.
\end{abstract}

Key words: Titanium, Surface modification, Hydrothermal treatment

\section{INTRODUCTION}

Titanium and its alloys have become popular as biomaterials in the dental and medical fields because of their excellent mechanical properties and biocompatibility ${ }^{1-13)}$. In particular, titanium materials for implantation of artificial tooth roots have been widely employed because of their osteointegration with bone tissues. However, titanium materials are less able to facilitate osteointegration or osteobonding than calcium phosphate materials such as apatites, calcium phosphate cements, bioglasses, and bioglass-ceramics. Therefore, various surface modification methods of titanium have been investigated and introduced in a bid to improve the activity of osteointegration ${ }^{1,14-18)}$. These methods can be roughly classified into two types - namely, chemical and physical processes. A common physical method for the surface modification of titanium substrates is plasma-spraying of calcium phosphate particles such as hydroxyapatite or tricalcium phosphate. Moreover, calcium ion implantation and apatite blast coating have been investigated as alternative physical methods for modifying titanium $^{19-22)}$. On the other hand, chemical surface modification of titanium substrates by means of treatment in solutions such as $\mathrm{NaOH}, \mathrm{H}_{2} \mathrm{O}_{2}, \mathrm{Ca}(\mathrm{OH})_{2}$ have also been investigated ${ }^{1,23-27)}$.

When bioactive materials such as hydroxyapatite are implanted into bone, they bond to living bone in the body via a bone-like apatite layer formed on their surface ${ }^{4,16,27,28)}$ - which is immediately precipitated from body fluid, forming a chemical bond with the bone. In vivo and in vitro investigations have revealed that the bone-like apatite precipitation on pure titanium is delayed in comparison with calcium phosphate materials. However, apatite precipitation on surface-modified titanium is more rapid than on pure titanium $^{14,15)}$. We previously investigated surface modification of titanium by a simple method using immersion in calcium-containing solutions ${ }^{14)}$. In that study, the surface-modified titanium effectively precipitated apatite in vitro, thus illustrating that surface-modified titanium is possibly superior to unmodified titanium in terms of bone conduction. Moreover, the titanium surface-modified by immersion in calcium-containing solutions was investigated by using an autoclave for sterilization $\left(121^{\circ} \mathrm{C}, 0.2\right.$ $\mathrm{MPa})^{1)}$. This was because in comparison to a simple immersion method, modification of titanium in a calcium-containing solution with hydrothermal treatment at low temperature and pressure $\left(121^{\circ} \mathrm{C}\right.$, $0.2 \mathrm{MPa})$ was expected to result in better osteointegration. Therefore, we considered that hydrothermal treatments (in calcium-containing solution) using an autoclave with a maximum pressure 6.3 $\mathrm{MPa}$ and temperature of $280^{\circ} \mathrm{C}$ might improve bioactivity such as the osteointegration of titanium. 
Further, the results of our previous investigation ${ }^{14)}$ led to the hypothesis that with increase of the titanium oxide or calcium titanate layer on the titanium surface, the osteointegration of titanium would improve accordingly.

In this study, surface modification of titanium was performed in calcium oxide $(\mathrm{CaO})$ and distilled water with high-pressure hydrothermal treatment in a special autoclave. The surface structure of titanium surface-modified by hydrothermal treatments was then investigated by X-ray photoelectron spectroscopy, X-ray diffractometry, and scanning electron microscopy, and the modificatory effects of various hydrothermal treatments on the titanium surface thereby discussed. Moreover, the influence of hydrothermal treatment on the bioactivity of surfacemodified titanium was examined by apatite precipitation with immersion in a simulated body fluid.

\section{MATERIALS AND METHODS}

\section{Preparation of titanium specimens}

Commercially pure titanium $(99.5 \%)$ plates were used. Each plate was $1 \mathrm{~mm}$ in thickness and $33 \mathrm{~mm}$ in diameter. The plates were metallographically polished with $\mathrm{SiC}$ papers, and final polishing was performed with \#800 SiC paper. After polishing, the plates were ultrasonically washed in acetone, ethyl alcohol, and distilled water for 15 minutes each and dried in a desiccator under reduced pressure for five hours. Next, they were weighed with a microbalance (accuracy $0.01 \mathrm{mg}$ ) and their dimensions measured.

\section{Surface modification}

Experimental procedures used for surface modification in this research are shown in Fig. 1. Hydrothermal treatment was performed using an autoclave (TVS-N2, Taiatsu Techno Co., Tokyo, Japan). The plates were treated by temperature and pressure conditions of $200^{\circ} \mathrm{C}$ and $1.4 \mathrm{MPa}$, or $280^{\circ} \mathrm{C}$ and $6.3 \mathrm{MPa}$, respectively, in the autoclave. These hydrothermal conditions were maintained for one hour. The liquid employed in the autoclave consisted of distilled water and $0.02 \mathrm{~mol} / \mathrm{L} \mathrm{CaO}$ aqueous solution. $\mathrm{CaO}$ is immediately transformed to calcium hydroxide, $\mathrm{Ca}(\mathrm{OH})_{2}$, in water. Therefore, $\mathrm{CaO}$ solution equals $\mathrm{Ca}(\mathrm{OH})_{2}$ solution. After treatment, the plates were rinsed in sterile distilled water, dried in a vacuum desiccator, and weighed again.

Immersion in $\mathrm{SBF}$

For the simulated body fluid (SBF), Hanks' solution was prepared without organic species and the $\mathrm{pH}$ of the solution was adjusted to 7.4 with $7.5 \% \quad \mathrm{NaHCO}_{3}$
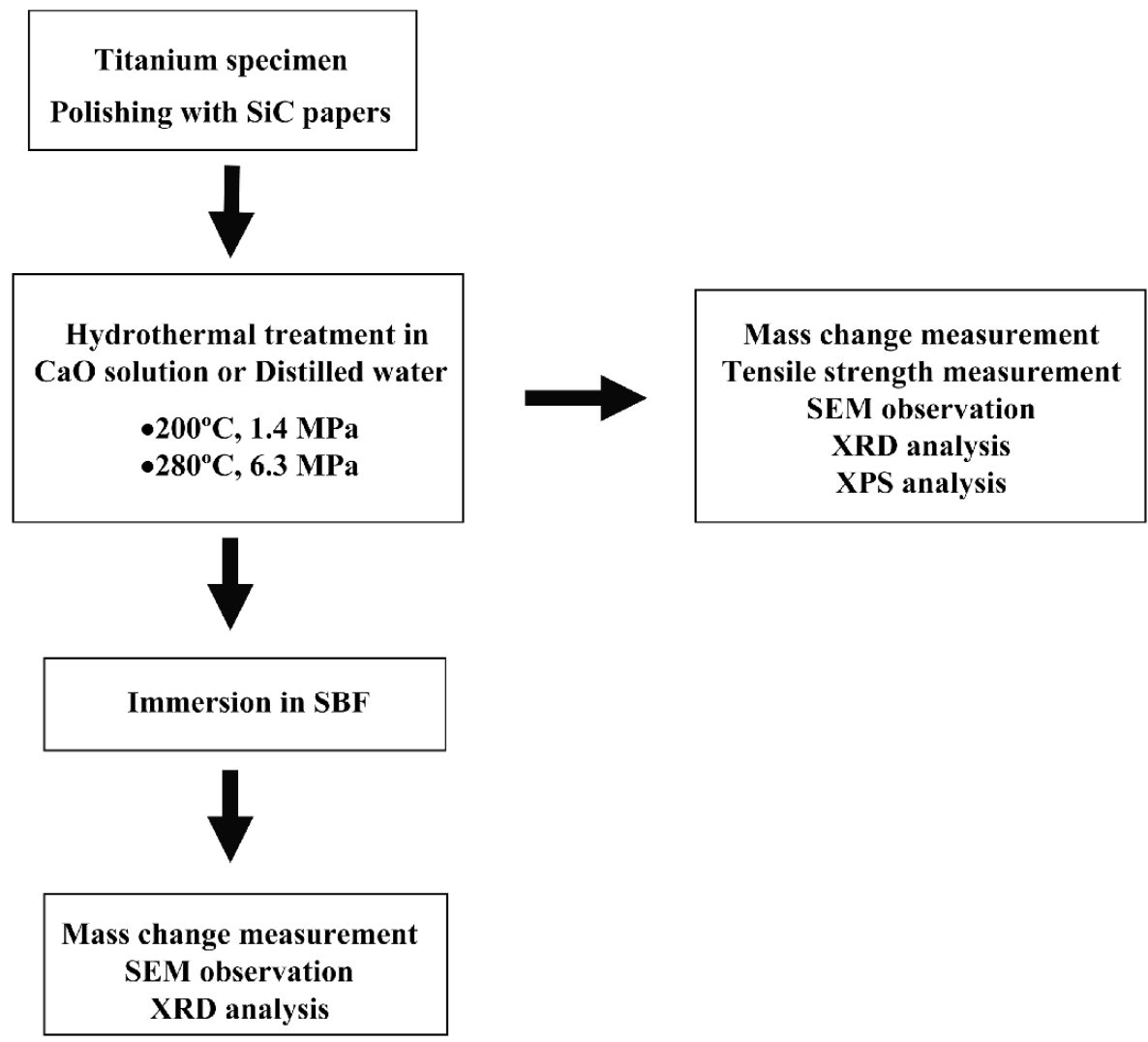

Fig. 1 Surface-modification method and analyses in this study. 
solution immediately after preparation. The final inorganic ion concentrations $(\mathrm{mol} / \mathrm{L})$ of the solution were $1.42 \times 10^{-1} \mathrm{Na}^{+}, 5.81 \times 10^{-3} \mathrm{~K}^{2+}, 8.11 \times 10^{-4}$ $\mathrm{Mg}^{2+}, \quad 1.26 \times 10^{-3} \mathrm{Ca}^{2+}, 1.45 \times 10^{-1} \mathrm{Cl}^{-}, 7.78 \times 10^{-4}$ $\mathrm{HPO}_{4}{ }^{2-}, 8.11 \times 10^{-4} \mathrm{SO}_{4}{ }^{2-}$, and $4.17 \times 10^{-3} \mathrm{CO}_{3}{ }^{2-}$. Surface-modified titanium plates were immersed in $37^{\circ} \mathrm{C}$ $\mathrm{SBF}$ in a Teflon-sealed bottle for one week and four weeks. Volume of the solution was $125 \mathrm{ml}$ per bottle and four plates were immersed in each bottle. Three plates were set vertically and one plate was laid at the bottom of the bottle. The SBF in the bottle was changed every three days to maintain the ionic concentrations because of precipitation from the SBF. No precipitates were confirmed to form in the solution or on the wall of the bottle. After immersion, the plates were rinsed in distilled water, dried in the vacuum desiccator, and weighed again. Mass change per unit surface area before and after immersion was determined.

\section{Analysis of specimens}

Specimen surface was characterized using X-ray photoelectron spectroscopy (XPS; Quantum 2000, PHI Co., USA) with an Al $\mathrm{K} \alpha$ line. Argon ion sputtering was carried out during XPS to examine the composition and structure of the surface layer. Sputtering time was one minute at $3 \mathrm{keV}$ and sputtering speed was approximately $37 \mathrm{~nm} / \mathrm{min}$ for $\mathrm{SiO}_{2}$. The $\mathrm{O}$ 1s spectrum in XPS spectra contained three peaks originating from $\mathrm{O}^{2-}, \mathrm{OH}^{-}$, and hydrate and/or water (Fig. 2) ${ }^{29)}$. Composition at three oxygen sites was evaluated according to the methods of Asami et $a l^{30,31)}$.

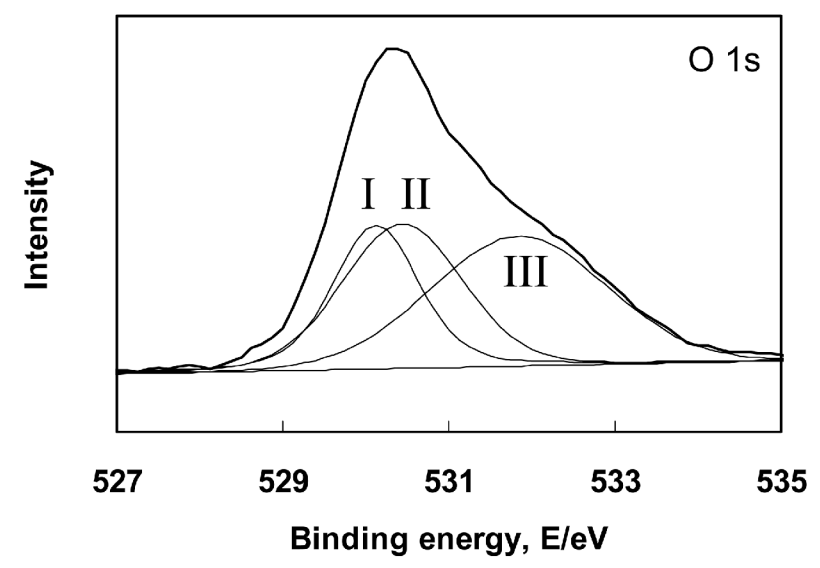

Fig. 2 O 1s XPS spectra obtained from titanium after hydrothermal treatment. 'I' indicates oxygen $(\mathrm{O})$, 'II' indicates hydroxyl group (OH), and 'III' indicates water $\left(\mathrm{H}_{2} \mathrm{O}\right)$.
A scanning electron microscope (SEM; JSM5600LV, JEOL, Tokyo, Japan) was used to observe the microstructure on the outermost surface layer of the specimens before and after immersion in SBF. For SEM observation, the specimens were sputtered with gold. The crystal phase of each specimen was analyzed using X-ray diffraction (XRD; Miniflex, Rigaku Co., Tokyo, Japan). The XRD conditions were $\mathrm{Ni}$ monochromatized $\mathrm{CuK} \alpha$ radiation $(\lambda=0.1540$ $\mathrm{nm}$ ) generated at $30 \mathrm{kV}$ and $15 \mathrm{~mA}$.

The influence of hydrothermal treatment on the mechanical properties of titanium specimens was also investigated in terms of tensile strength. Tensile strength of the specimens $(1 \mathrm{~mm} \phi \times 50 \mathrm{~mm})$ was measured using a universal testing machine (Autograph AGS-500A, Shimadzu Co., Kyoto, Japan) with a crosshead speed of $0.5 \mathrm{~mm} / \mathrm{min}$.

\section{RESULTS}

SEM micrograph of non-treated titanium specimen (as a control) is shown in Fig. 3, while those of hydrothermal-treated specimens at $200^{\circ} \mathrm{C}(1.4 \mathrm{MPa})$ and $280^{\circ} \mathrm{C}(6.3 \mathrm{MPa})$ in $\mathrm{CaO}$ solution and distilled water are shown in Fig. 4. No significant differences between before and after several hydrothermal treatments were confirmed by SEM observations of the surface structure on specimens. Fig. 5 shows the XRD patterns of titanium specimens before and after several hydrothermal treatments. Non-treated specimen had XRD peaks only for titanium (Ti) crystals and no peaks were confirmed for the other crystals. After the titanium specimens were treated at $200^{\circ} \mathrm{C}$

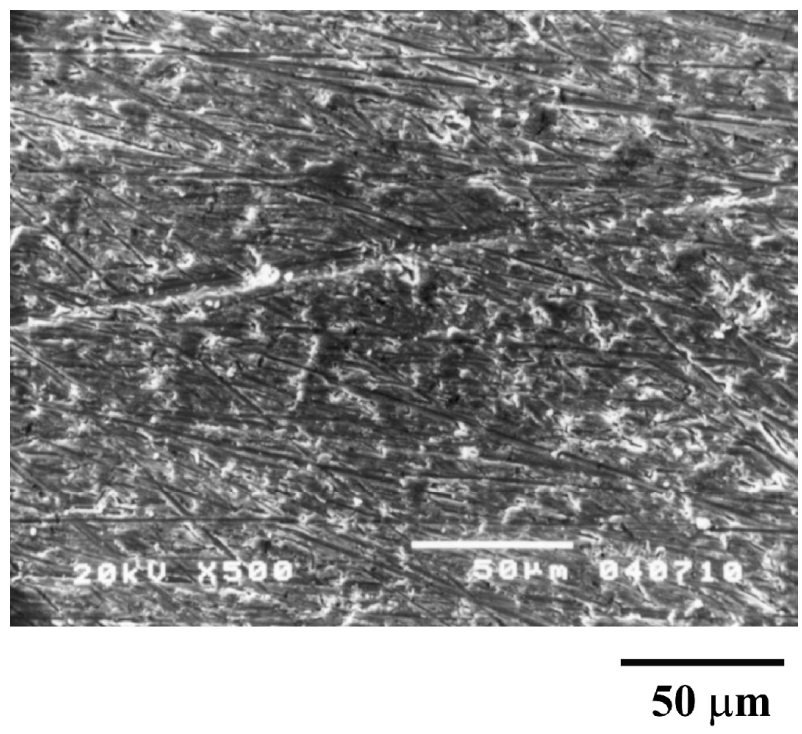

Fig. 3 Scanning electron micrograph (SEM) showing the surface of non-treated titanium specimen. 

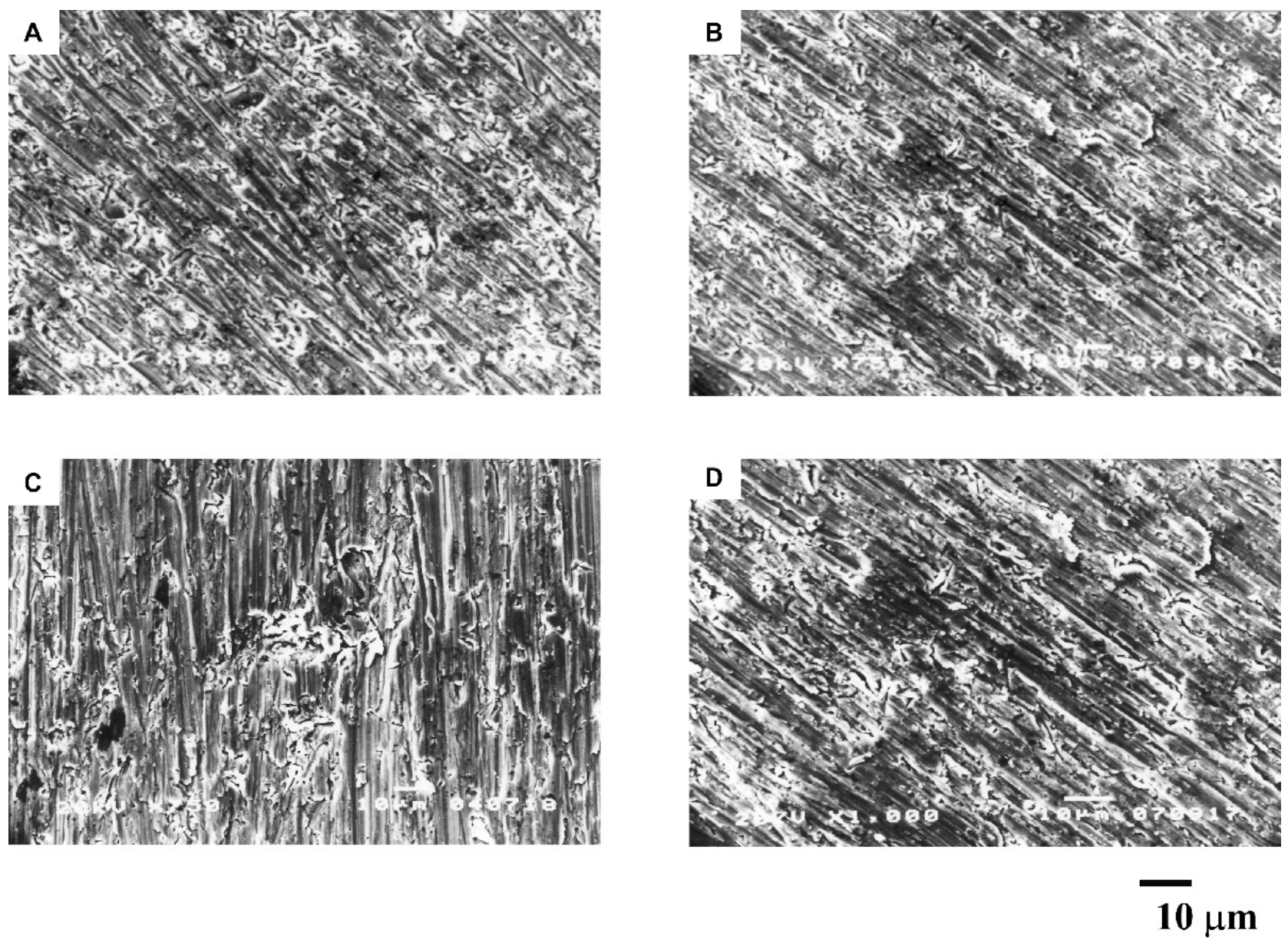

Fig. 4 Scanning electron micrographs (SEM) showing the surface of titanium specimens with hydrothermal treatment (HT). A: HT at $200^{\circ} \mathrm{C}$ in water; B: HT at $280^{\circ} \mathrm{C}$ in water; C: HT at $200^{\circ} \mathrm{C}$ in $\mathrm{CaO}$ solution; and D: HT at $280^{\circ} \mathrm{C}$ in $\mathrm{CaO}$ solution.

(1.4 MPa) or $280^{\circ} \mathrm{C}(6.3 \mathrm{MPa})$ in $\mathrm{CaO}$ solution, small peaks for anatase $\left(\mathrm{TiO}_{2}\right)$ and calcium titanate $\left(\mathrm{CaTiO}_{3}\right)$ were fractionally detected by XRD. Moreover, a small XRD peak for anatase $\left(\mathrm{TiO}_{2}\right)$ was also confirmed for the specimen treated at $280{ }^{\circ} \mathrm{C} \quad(6.3$ $\mathrm{MPa}$ ) in distilled water.

Table 1 shows the compositions of surface layers on the hydrothermal-treated specimens, calculated from XPS spectra. In the specimen treated at 200 ${ }^{\circ} \mathrm{C}$ in distilled water, the outermost layer had a composition of $33 \%$ titanium ( $\mathrm{Ti}$ ) and $66 \%$ oxygen $(\mathrm{O})$, that is, almost pure $\mathrm{TiO}_{2}$. The oxygen component of the specimen treated at $280^{\circ} \mathrm{C}$ was greater than that at $200^{\circ} \mathrm{C}$. After sputtering, composition of the second layer on the specimen surfaces treated in water were the same as those of the outermost layers. Surface layers of specimens treated in $\mathrm{CaO}$ solution were composed of calcium (Ca) and oxygen, and there was almost no titanium in the outermost and second surface layers. The relations of oxygen (O), hydroxyl group $(\mathrm{OH})$, and water $\left(\mathrm{H}_{2} \mathrm{O}\right)$ contents on the surfaces of hydrothermal-treated specimens, calculated from $O$ 1s XPS spectra, are shown in Table 2. In the outermost surface layer for all hydrothermal treatments, the $\left(\mathrm{H}_{2} \mathrm{O}+\mathrm{OH}\right) / \mathrm{O}$ ratio of the titanium surfaces increased more than the $\mathrm{OH} / \mathrm{O}$ ratio. The $\mathrm{OH}$ group content on the outermost surface layer increased with treatment in $\mathrm{CaO}$ solution as compared with treatment in water. The $\mathrm{OH}$ group with treatment in $\mathrm{CaO}$ solution might be due to adsorption of $\mathrm{Ca}(\mathrm{OH})_{2}$ because titanium constituent did not exist in the surface layer (Table 1). The influences of temperature and pressure of hydrothermal treatment on the $\mathrm{OH}$ group and $\mathrm{H}_{2} \mathrm{O}$ contents could not be confirmed. After sputtering with argon, the $\mathrm{OH}$ group content in the second surface layer decreased more than that in the outermost surface layer. In particular, for specimens treated in $\mathrm{CaO}$ solution, their $\mathrm{OH}$ group content markedly decreased with sputtering.

Fig. 6 shows the SEM observations of titanium specimens with hydrothermal treatment (A, B, C, D) and without treatment $(\mathrm{N})$ after immersion in $\mathrm{SBF}$ 
Table 1 Surface composition of titanium specimens after hydrothermal treatment (XPS)

Outermost layer

\begin{tabular}{cccccc}
\hline & & & \multicolumn{3}{c}{ Composition (atomic\%) } \\
\cline { 3 - 5 } & & & $\mathrm{Ti}$ & $\mathrm{Ca}$ & $\mathrm{O}$ \\
\hline $200^{\circ} \mathrm{C}$ & $1.4 \mathrm{MPa}$ & Water & 32.9 & - & 65.6 \\
$280^{\circ} \mathrm{C}$ & $6.3 \mathrm{MPa}$ & Water & 20.1 & - & 78.4 \\
$200^{\circ} \mathrm{C}$ & $1.4 \mathrm{MPa}$ & $\mathrm{CaO}$ solution & - & 12.7 & 87.4 \\
$280^{\circ} \mathrm{C}$ & $6.3 \mathrm{MPa}$ & $\mathrm{CaO}$ solution & 4.1 & 33.9 & 62.1 \\
\hline
\end{tabular}

After sputtering

\begin{tabular}{llcccc}
\hline & & & \multicolumn{3}{c}{ Composition (atomic\%) } \\
\cline { 4 - 6 } & & & $\mathrm{Ti}$ & $\mathrm{Ca}$ & $\mathrm{O}$ \\
\hline $200^{\circ} \mathrm{C}$ & $1.4 \mathrm{MPa}$ & Water & 35.9 & - & 63.8 \\
$280^{\circ} \mathrm{C}$ & $6.3 \mathrm{MPa}$ & Water & 20.4 & - & 79.0 \\
$200^{\circ} \mathrm{C}$ & $1.4 \mathrm{MPa}$ & $\mathrm{CaO}$ solution & - & 19.3 & 80.7 \\
$280^{\circ} \mathrm{C}$ & $6.3 \mathrm{MPa}$ & $\mathrm{CaO}$ solution & 2.0 & 16.6 & 81.3 \\
\hline
\end{tabular}

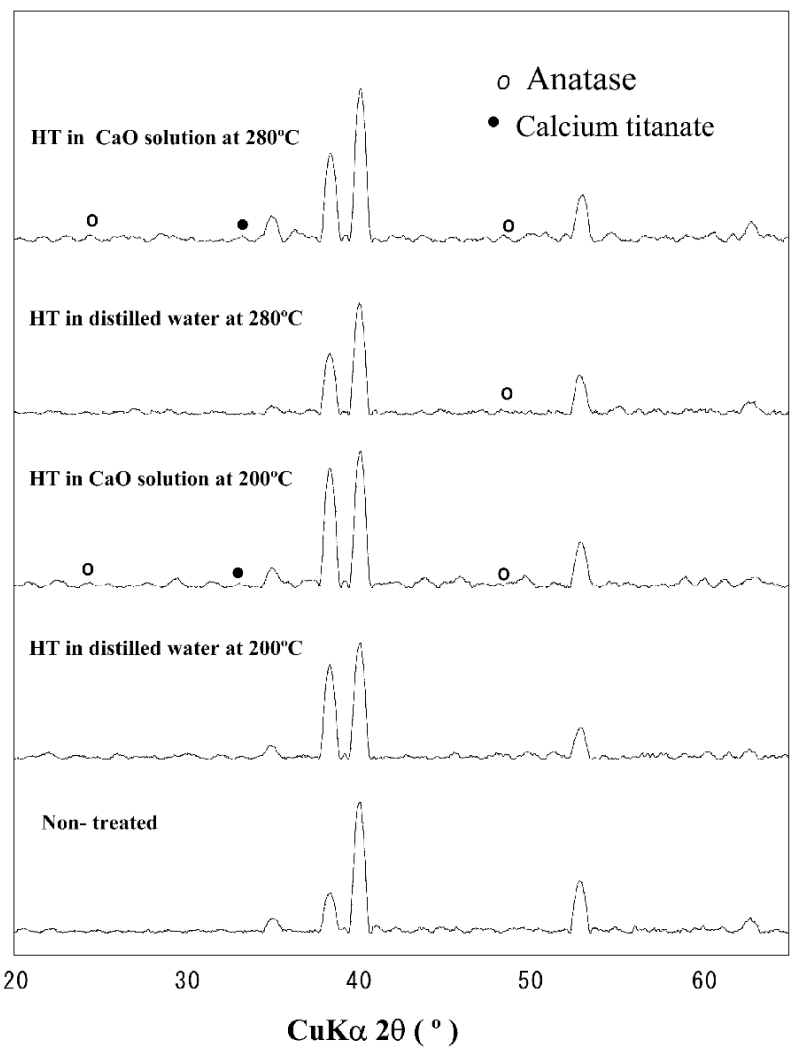

Fig. 5 X-ray diffraction patterns of titanium specimens, before and after hydrothermal treatment (HT).

for one and four weeks. Almost no precipitates were observed on the non-treated specimens after immersion in SBF for one $\left(\mathrm{N}_{1}\right)$ and four weeks $\left(\mathrm{N}_{4}\right)$. With hydrothermal treatment, precipitates were confirmed on the surfaces of all specimens. However, there was little on the titanium treated in $\mathrm{CaO}$ solution at 200 ${ }^{\circ} \mathrm{C}$ after immersion for one week $\left(\mathrm{C}_{1}\right)$. All hydrothermal-treated specimens immersed for four weeks had a greater amount of precipitate than at one week. High-magnification SEM photographs of the treated specimens immersed in SBF for four weeks are shown in Fig. 7. The surfaces of all treated specimens had precipitates with needle-like and island-like crystals. Island-like precipitates of the titanium treated in $\mathrm{CaO}$ solution at $200^{\circ} \mathrm{C}$ were larger than those of the other treatments. Fig. 8 shows the XRD pattern of a specimen treated in $\mathrm{CaO}$ solution at $280^{\circ} \mathrm{C}$, after immersion in $\mathrm{SBF}$ for four weeks. The XRD pattern indicated that the precipitates on the titanium specimen were apatite crystals because of the bump peak range from $2 \theta 30^{\circ}$ to $32^{\circ}$ for the apatite crystal. Mass changes of the treated specimens before and after immersion in SBF for one and four weeks are shown in Fig. 9. There were no differences in mass change between the plates set vertically and that laid at the bottom. The mass of all specimens increased with immersion in SBF. However, the mass of non-treated titanium decreased slightly after immersion in SBF for four weeks. As for the treated specimens, their mass increased remarkably after immersion in SBF for four weeks as compared to their mass after one week's immersion (ANOVA, $\mathrm{p}<0.05$ ), except for the specimen treated in water at $200^{\circ} \mathrm{C}(\mathrm{p}>0.05)$. In particular, mass of the specimen treated in $\mathrm{CaO}$ solution at 280 ${ }^{\circ} \mathrm{C}$ was remarkably increased compared with those of the other specimens. A correlation was thus estimated from the results of mass change measurement and SEM observation.

The mean tensile strength values of non-treated and treated specimens are shown in Table 3 . No influence of hydrothermal treatment on the strength of titanium specimens was confirmed. 
Table 2 Relation between oxygen $(\mathrm{O})$, hydroxyl group $(\mathrm{OH})$, and water $\left(\mathrm{H}_{2} \mathrm{O}\right)$ contents on the surface layer of titanium specimens after hydrothermal treatment (XPS)

Outermost layer

\begin{tabular}{ccccc}
\hline & & & $\mathrm{OH} / \mathrm{O}$ & $\left(\mathrm{H}_{2} \mathrm{O}+\mathrm{OH}\right) / \mathrm{O}$ \\
\hline $200^{\circ} \mathrm{C}$ & $1.4 \mathrm{MPa}$ & Water & 0.46 & 0.51 \\
$280^{\circ} \mathrm{C}$ & $6.3 \mathrm{MPa}$ & Water & 0.39 & 0.46 \\
$200^{\circ} \mathrm{C}$ & $1.4 \mathrm{MPa}$ & $\mathrm{CaO}$ solution & 2.48 & 3.32 \\
$280^{\circ} \mathrm{C}$ & $6.3 \mathrm{MPa}$ & $\mathrm{CaO}$ solution & 1.80 & 2.19 \\
\hline
\end{tabular}

\begin{tabular}{llcc}
\multicolumn{2}{l}{ After sputtering } & \\
\hline & & & $\mathrm{OH} / \mathrm{O}$ \\
\hline $200^{\circ} \mathrm{C}$ & $1.4 \mathrm{MPa}$ & Water & 0.20 \\
$280^{\circ} \mathrm{C}$ & $6.3 \mathrm{MPa}$ & Water & 0.21 \\
$200^{\circ} \mathrm{C}$ & $1.4 \mathrm{MPa}$ & $\mathrm{CaO}$ solution & 0.36 \\
$280^{\circ} \mathrm{C}$ & $6.3 \mathrm{MPa}$ & $\mathrm{CaO}$ solution & 0.29 \\
\hline
\end{tabular}
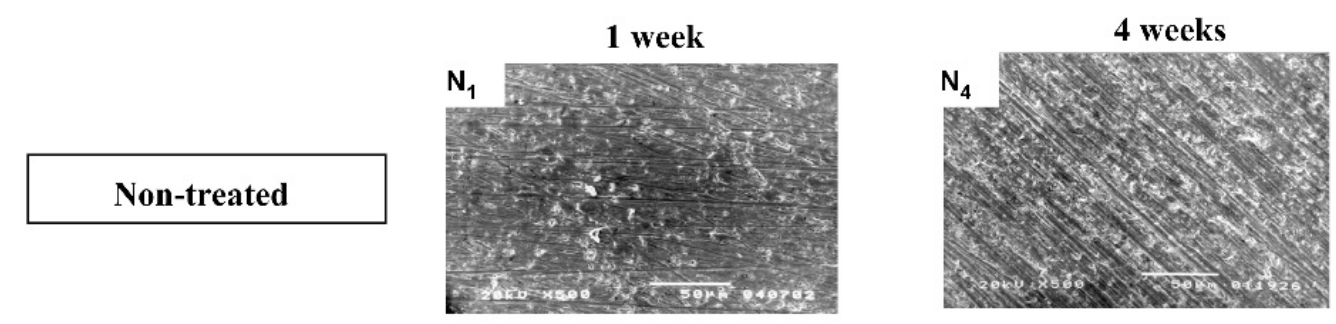

HT in water at $200^{\circ} \mathrm{C}$
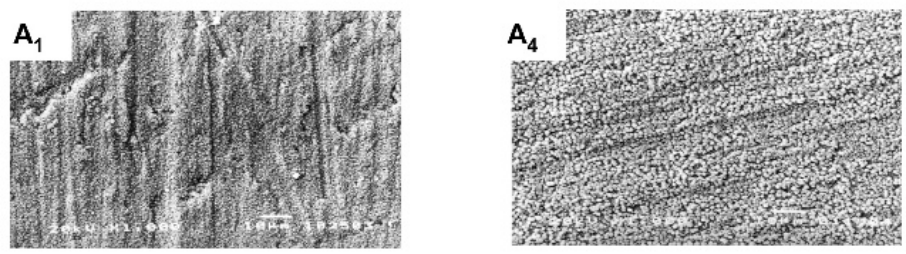

\section{$\mathrm{HT}$ in water at $280^{\circ} \mathrm{C}$}

\section{$\mathrm{HT}$ in $\mathrm{CaO}$ solution at $200^{\circ} \mathrm{C}$}
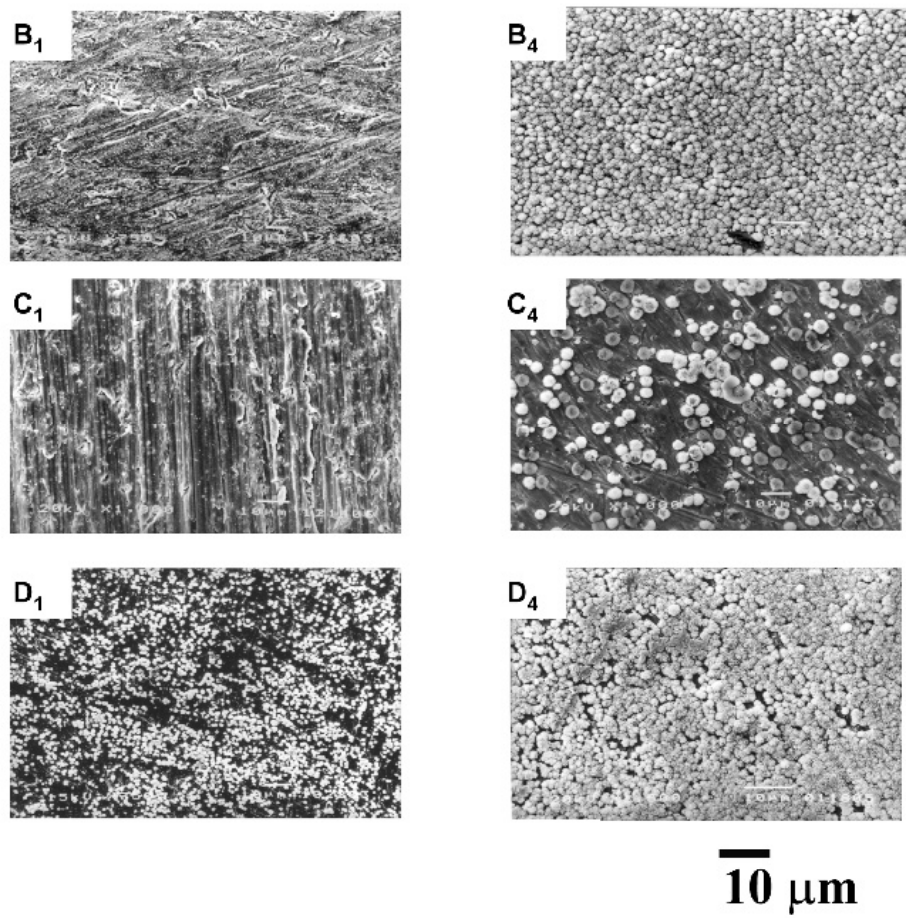

Fig. 6 Scanning electron micrographs (SEM) showing the surface of titanium specimens with hydrothermal treatment, HT (A, B, C, D) and without HT (N) after immersion in SBF for 1 and 4 weeks. 

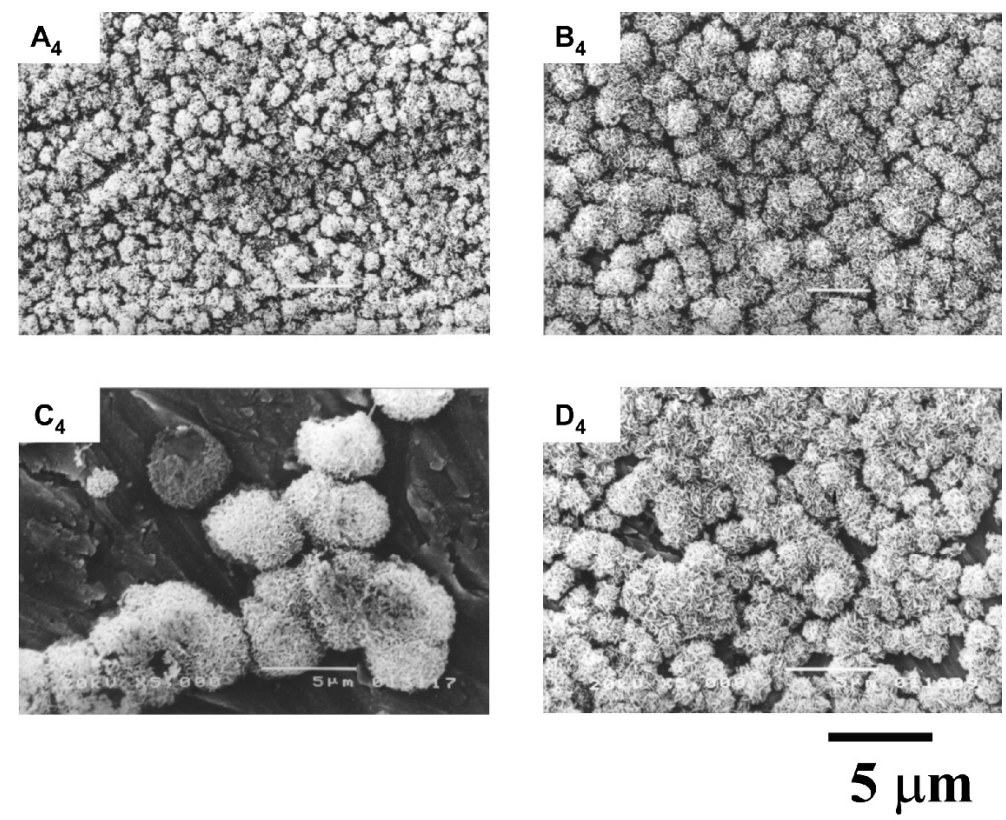

Fig. 7 Scanning electron micrographs (SEM) showing the surface of titanium specimens with hydrothermal treatment (HT) after immersion in SBF for 4 weeks. A: HT at $200^{\circ} \mathrm{C}$ in water; B: HT at $280^{\circ} \mathrm{C}$ in water; C: $\mathrm{HT}$ at $200^{\circ} \mathrm{C}$ in $\mathrm{CaO}$ solution; and D: $\mathrm{HT}$ at $280^{\circ} \mathrm{C}$ in $\mathrm{CaO}$ solution.

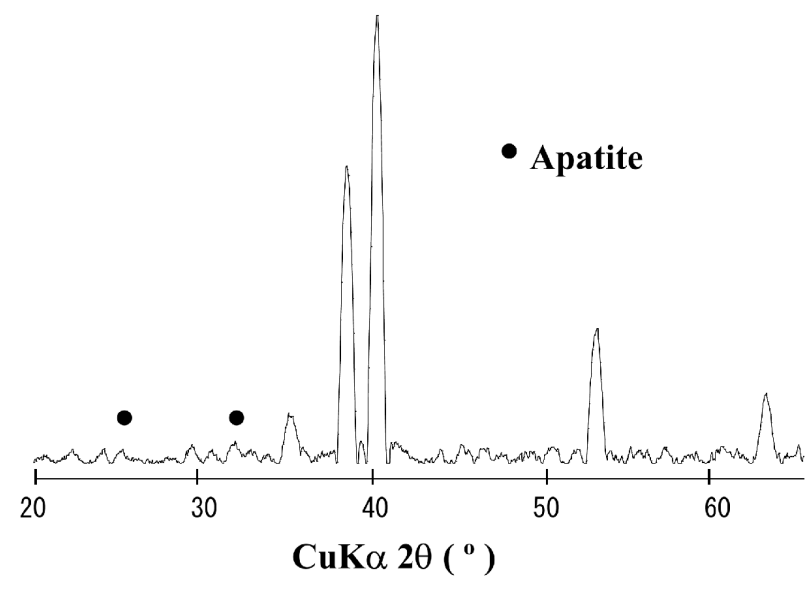

Fig. 8 X-ray diffraction pattern of titanium specimen with hydrothermal treatment (HT) at $280^{\circ} \mathrm{C}$ in $\mathrm{CaO}$ solution after immersion in SBF for 4 weeks.

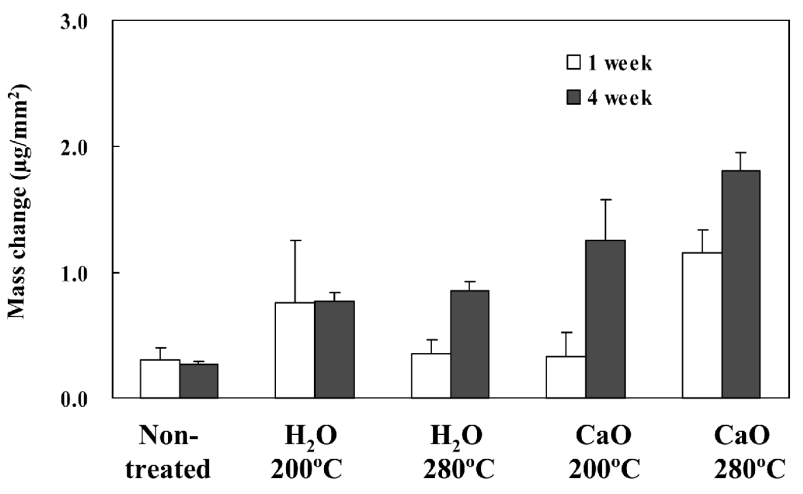

Fig. 9 Relationship between mass change and temperature of surface-modified titanium with immersion in $\mathrm{SBF}$ solution at $37^{\circ} \mathrm{C}$ for 1 and 4 weeks.

Table 3 Comparison of tensile strengths of titanium specimens after hydrothermal treatment (HT) in water and $\mathrm{CaO}$ solution

\begin{tabular}{|c|c|c|}
\hline \multicolumn{2}{|c|}{ Treatment } & Tensile strength, MPa \\
\hline \multirow{3}{*}{ HT in Water } & $121^{\circ} \mathrm{C} \quad 0.2 \mathrm{MPa}$ & $394 \quad(1)$ \\
\hline & $200^{\circ} \mathrm{C} \quad 1.4 \mathrm{MPa}$ & $395(1)$ \\
\hline & $280^{\circ} \mathrm{C} \quad 6.3 \mathrm{MPa}$ & $390(3)$ \\
\hline \multirow{3}{*}{$\mathrm{HT}$ in $\mathrm{CaO}$ solution } & $121^{\circ} \mathrm{C} \quad 0.2 \mathrm{MPa}$ & $385(3)$ \\
\hline & $200^{\circ} \mathrm{C} \quad 1.4 \mathrm{MPa}$ & $388(3)$ \\
\hline & $280^{\circ} \mathrm{C} \quad 6.3 \mathrm{MPa}$ & $385(2)$ \\
\hline Non-treated & & $389(2)$ \\
\hline
\end{tabular}




\section{DISCUSSION}

Surface modification of titanium due to hydrothermal treatments

High-pressure hydrothermal treatments are known to induce various reactions that do not occur at atmospheric pressure. We demonstrated that titanium specimens with hydrothermal treatment in calciumcontaining solutions at $121^{\circ} \mathrm{C}(0.2 \mathrm{MPa})$ showed more effective bioactivity than those only immersed in calcium-containing solutions ${ }^{1,14)}$. The hydrothermal treatment used in this study applied a maximum temperature and pressure of $280^{\circ} \mathrm{C}$ and $6.3 \mathrm{MPa}$ respectively, the high pressure being 60 times more than that of normal atmosphere.

The XRD pattern of non-treated titanium did not reveal the presence of titanium oxide because the oxide film of titanium was remarkably thin. However, the XRD patterns revealed that hydrothermal treatment in $\mathrm{CaO}$ solution increased the thickness of titanium oxide film as compared with that in water. Moreover, crystallization of calcium titanate $\left(\mathrm{CaTiO}_{3}\right)$ was confirmed by the XRD patterns of specimens treated in $\mathrm{CaO}$ solution. We have proved that calcium titanate on the surface of titanium had more effective bioactivity for osteointegration than anatase $\left(\mathrm{TiO}_{2}\right)$ or rutile $\left(\mathrm{TiO}_{2}\right)$ on the surface ${ }^{32}$. In our previous study, the crystallinity of calcium titanate was increased by hydrothermal treatment at $121^{\circ} \mathrm{C}$ and $0.2 \mathrm{MPa}$ in $\mathrm{CaO}$ solution as compared with the case of mere immersion in the same solution ${ }^{1)}$. Therefore, even a hydrothermal treatment at low temperature and pressure $\left(121^{\circ} \mathrm{C}\right.$ and $\left.0.2 \mathrm{MPa}\right)$ used for sterilization could induce a reaction that did not occur under atmospheric pressure at $121^{\circ} \mathrm{C}$. It was therefore hypothesized that the crystallinity of calcium titanate could be increased by increasing the pressure and temperature of hydrothermal treatments. The crystallinity of calcium titanate and exact thickness of the titanium oxide film on the titanium surface could not be estimated by XRD measurement because the crystal phase of the titanium surface in this study was not measured using thin-film XRD. However, XRD measurement implied that the thickness of titanium oxide film and calcium titanate film on the surface layer increased with increase in hydrothermal pressure (Fig. 5). Further, XPS measurement also revealed that the $\mathrm{OH}$ group content in the surface layer was increased by hydrothermal treatment (Table 2). OH groups on the surface of titanium are known to be effective for biocompatibility and bioactivity in osteointegration ${ }^{1,32)}$.

By physical estimation, it could be said that the mechanical properties of titanium specimens were reduced by hydrothermal treatments at high pressure because a surface layer was introduced on titanium whereby thickness of oxide film increased with increase in pressure, and likewise the constituent types in the surface layer. However, the surface layer introduced by hydrothermal treatments was very thin. Therefore, for titanium specimens with $1 \mathrm{~mm}$ diameter, their tensile strength was not affected.

\section{Immersion in SBF for surface-modified titanium}

In the evaluation of biomaterials such as bone substitutes, SBF is the de facto immersion solution used to reproduce in vivo surface structure changes ${ }^{33-35)}$. It is known that carbonated apatite is precipitated on the surfaces of materials by immersion in SBF because of its biocompatibility and bioactivity, that is, osteointegration and osteobonding. Evaluation is then performed by observing the precipitation time and volume of the apatite formed ${ }^{35,36)}$. In fact, since 10 years ago, we have been trying to adopt weight measurement for the estimation of precipitation volume with immersion in $\mathrm{SBF}^{1,14,35,37)}$.

For precipitation on the surfaces of specimens after immersion in SBF, there was a relation between SEM observation (Fig.6) and weight measurement (Fig. 9). Results after immersion in SBF for four weeks showed that hydrothermal treatment in water was more effective for apatite precipitation on the titanium surface than no hydrothermal treatment. This was the reason why a large quantity of $\mathrm{OH}$ groups and a thick layer of $\mathrm{TiO}_{2}$ appeared on the surface of titanium with hydrothermal treatment in water, as shown in Fig. 9. With hydrothermal treatment in $\mathrm{CaO}$ solution, precipitates on the titanium surface were larger than those of hydrothermal treatment in water and no hydrothermal treatment. One reason was because $\mathrm{OH}$ groups increased remarkably on the surface of titanium with hydrothermal treatment in $\mathrm{CaO}$ solution (Table 2). Moreover, in the surface layer of titanium with hydrothermal treatment in $\mathrm{CaO}$ solution, there was almost no $\mathrm{TiO}_{2}$ because $\mathrm{Ca}(\mathrm{OH})_{2}$ was adsorbed and calcium titanate $\left(\mathrm{CaTiO}_{3}\right)$ was introduced by the hydrothermal reaction (Fig. 5, Table 1). Calcium titanate on the surface of titanium had more effective bioactivity than anatase $\left(\mathrm{TiO}_{2}\right)$ and rutile $\left(\mathrm{TiO}_{2}\right)^{34)}$. CaO solution, i.e., $\mathrm{Ca}(\mathrm{OH})_{2}$ solution, has a high $\mathrm{pH}$ value and apatite precipitation might be increased by the high $\mathrm{pH}$ on the surface ${ }^{1,14)}$. Thus, hydrothermal treatment in $\mathrm{CaO}$ solution was most effective for apatite precipitation.

Results of this study suggested that hydrothermal treatments at $1.4 \mathrm{MPa}$ and $6.3 \mathrm{MPa}$ could be effective for surface modification of titanium as an implant material compared with hydrothermal treatment at $0.2 \mathrm{MPa}$ and no hydrothermal treatment. Moreover, they revealed that hydrothermal treatment in $\mathrm{CaO}$ solution was better for the surface modification of titanium than in water. Better precipitation of bone-like apatite on surface-modified titanium will lead to rapid osteointegration with bone when implanted in the body as an artificial tooth 
root. Leveraging on the results of this study, the clinical applicability and availability of high-pressure hydrothermal treatments - as a surface modification technique for titanium - should be further assessed in the future by evaluating osteointegration in in vivo animal experiments and in vitro cell cultures.

\section{ACKNOWLEDGEMENTS}

We are pleased to acknowledge the considerable assistance of Prof. Takao Hanawa, Institute of Biomaterials and Bioengineering, Tokyo Medical and Dental University.

\section{REFERENCES}

1) Hamada K, Kon M, Hanawa T, Yokoyama K, Miyamoto Y, Asaoka K. Hydrothermal modification of titanium surface in calcium solutions. Biomater 2002; 23: 2265-2272.

2) Sato H, Komatsu M, Miller B, Shimizu H, Fujii H, Okabe T. Mold filling and microhardness of $1 \% \mathrm{Fe}$ titanium alloys. Dent Mater J 2004; 23(2): 211-217.

3) Williams DF. Titanium alloy. In: Biocompatibility of clinical implant materials, Vol. 1, DF Williams (ed.), CRC Press, Boca Ration, Florida, 1981, pp.9-44.

4) Barrere F, van Blitterswijk CA, de Groot K, Layrolle $\mathrm{P}$. Influence of ionic strength and carbonate on the Ca$\mathrm{P}$ coating formation from $\mathrm{SBF} \times 5$ solution. Biomater 2002; 23: 1921-1930.

5) Liang B, Fujibayashi S, Neo M, Tamura J, Kim HM, Uchida M, Kokubo T, Nakamura T. Histological and mechanical investigation of the bone-bonding ability of anodically oxidized titanium in rabbits. Biomater 2003; 24: 4959-4966

6) Feng B, Chen JY, Qi SK, He L, Zhao JZ, Zhang XD. Characterization of surface oxide films on titanium and bioactivity. J Mater Sci Mater in Med 2002; 13: 457-464.

7) Takahashi M, Kikuchi M, Okuno O. Mechanical properties and grindability of experimental Ti-Au alloys. Dent Mater J 2004; 23 (2): 203-210.

8) Kikuchi H, Onouchi M, Miyanaga K, Wakashima M, Okuno O, Nishiyama M. The thickness effects of titanium castings on the surface reaction layer. Dent Mater J 2004; 23(3): 387-394.

9) Okawa S, Hossain A, Kanatani M, Watanabe K, Miyakawa O. Surface properties of electrochemically buffed titanium casting. Dent Mater J 2004; 23 (4) : 504511.

10) Nakagawa $M$, Zhang L, Udoh K, Matsuya S, Ishikawa K. Effects of hydrothermal treatment with $\mathrm{CaCl}_{2}$ solution on surface property and cell response of titanium implants. J Mater Sci Mater in Med 2005; 16: 985-991.

11) Suzuki T, Takahashi H, Arksornnukit M, Oda N. Bonding properties of heat-polymerized denture base resin to Ti-6AL-7Nb alloy. Dent Mater J 2005; 24(4): 530-535.

12) Srimaneepong S, Yoneyama $T$, Kobayashi E, Doi H, Hanawa T. Mechanical strength and microstructure of laser-welded Ti-6Al-7Nb alloy castings. Dent Mater J 2005; 24 (4): 541-549.

13) Nikawa H, Ishida K, Hamada T, Satoda T, Murayama T, Takemoto T, Tamamoto M, Tajima H, Shimoe S, Fujimoto H, Makihira S. Immobilization of octadecyl ammonium chloride on the surface of titanium and its effect on microbial colonization in vitro. Dent Mater J 2005; 24 (4): 570-582.

14) Hanawa T, Kon M, Ukai H, Murakami K, Miyamoto Y, Asaoka K. Surface modification of titanium in calcium-ion-containing solutions. J Biomed Mater Res 1997; 34: 273-278.

15) Kim DG, Shin MJ, Kim KH, Hanawa T. Surface treatments of titanium in aqueous solutions containing calcium and phosphate ions. Biomed Mater Eng 1999; 9: 89-96.

16) Jonasova L, Muller FA, Helebrant A, Strnad J, Greil P. Hydroxyapatite formation on alkali-treated titanium with different content of $\mathrm{Na}^{+}$in the surface layer. Biomater 2002; 23: 3095-3101.

17) Rodriguez R, Kim K, Ong JL. In vitro osteoblast response to anodized titanium and anodized titanium followed by hydrothermal treatment. J Biomed Mater Res 2003; 65A: 352-358.

18) Yuda A, Ban S, Izumi Y. Biocompatibility of apatitecoated titanium mesh prepared by hydrothermalelectrochemical method. Dent Mater J 2005; 24(4): 588595.

19) Ishikawa K, Miyamoto $Y$, Nagayama M, Asaoka K. Blast coating method: New method of coating titanium surface with hydroxyapatite at room temperature. J Biomed Mater Res 1997; 38: 129-134.

20) Mano $T$, Ueyama $Y$, Ishikawa $K$, Matsumura $T$, Suzuki K. Initial tissue response to a titanium implant coated with apatite at room temperature using a blast coating method. Biomater 2002; 23: 1931-1936.

21) Hanawa T, Murakami K, Kihara S. Calcium phosphate precipitation on calcium-ion-implanted titanium in electrolyte. In: Characterization and performance of calcium phosphate coatings for implants, Horowitz E and Parr JE (ed.), ASTM STP 1196, Philadelphia, 1994, p.170-184.

22) Hanawa T, Nodasaka $Y$, Ukai H, Murakami K, Asaoka K. Compatibility of MC3T3-E1 cells with calcium-ion-implanted titanium. J Jpn Soc Biomater 1994; 12: $209-216$

23) Wang XX, Hayakawa S, Tsuru K, Osaka A. Improvement of bioactivity of $\mathrm{H}_{2} \mathrm{O}_{2} / \mathrm{TaCl}_{5}$-treated titanium after subsequent heat treatments. J Biomed Mater Res 2000; 52: 171-176.

24) Kim HM, Miyaji F, Kokubo T, Nakamura T. Preparation of bioactive $\mathrm{Ti}$ and its alloys via simple chemical surface treatment. J Biomed Mater Res 1996; 32: 409417.

25) Kim HM, Miyaji F, Kokubo T, Nakamura T. Effect of heat treatment on apatite-forming ability of $\mathrm{Ti}$ metal induced by alkali treatment. $J$ Mater Sci Mater in Med 1997; 8: 341-347.

26) Wen HB, Liu Q, de Wijin JR, de Groot K. Preparation of bioactive Ti6Al4V surfaces by a simple method. 
Biomater 1998; 19: 215-221.

27) Kim HM, Takadama H, Kokubo T, Nishiguchi S, Nakamura T. Formation of a bioactive graded surface structure on Ti-15Mo-5Zr-3Al alloy by chemical treatment. Biomater 2000; 21: 353-358.

28) Fujibayashi S, Neo M, Kim HM, Kokubo T, Nakamura T. A comparative study between in vivo bone ingrowth and in vitro apatite formation on $\mathrm{Na}_{2} \mathrm{O}-\mathrm{CaO}-\mathrm{SiO}_{2}$ glasses. Biomater 2003; 24: 1349-1356.

29) Asami K, Hashimoto K. The X-ray photo-electron spectra of several oxides of ion and chromium. Corros Sci 1977; 17: 559-570.

30) Asami K, Hashimoto K, Shimodaira S. XPS determination of compositions of alloy surfaces and surface oxides on mechanically polished iron-chromium alloys. Corros Sci 1977; 17: 713-723.

31) Asami K, Hashimoto K. An XPS study of the surfaces on $\mathrm{Fe}-\mathrm{Cr}, \mathrm{Fe}-\mathrm{Co}$ and $\mathrm{Fe}-\mathrm{Ni}$ alloys after mechanical polishing. Corros Sci 1984; 24: 83-97.

32) Hanawa $\mathrm{T}$, Kon M, Doi $\mathrm{H}$, Ukai $\mathrm{H}$, Murakami $\mathrm{K}$, Hamanaka H, Asaoka K. Amount of hydroxyl group on calcium-ion-implantated titanium and point of zero charge of constituent oxide of the surface-modified layer. J Mater Sci Mater in Med 1998; 9: 89-92.

33) Kokubo T, Kushitani H, Sakka S. Solutions able to reproduce in vivo surface structure changes in bioactive glass-ceramic A-W³. J Biomed Mater Res 1990; 24: 721734 .

34) Kokubo T, Miyaji F, Kim HM, Nakamura T. Spontaneous apatite formation on chemically treated titanium metals. J Am Ceram Soc 1996; 79: 1127-1129.

35) Hirakata LM, Kon M, Asaoka K. Evaluation of apatite ceramics containing $\alpha$-tricalcium phosphate by immersion in simulated body fluid. Biomed Mater Eng 2003; 13: 247-259.

36) Uchida M, Kim HM, Kokubo T, Nawa M, Asano T, Tanaka K, Nakamura T. Apatite-forming ability of a zirconia/alumina nano-composite induced by chemical treatment. J Biomed Mater Res 2002; 60: 277-282.

37) Fukao H, Miyamoto Y, Sawada M, Nagayama M, Kon $\mathrm{M}$, Ishikawa K, Asaoka K. In vivo reactions of functionally gradient ceramic calcium phosphate. In: The $3^{\text {rd }}$ World Congress for Oral Implantology, Program \& Abstracts, Yokohama, Japan, 1994, p.315. 